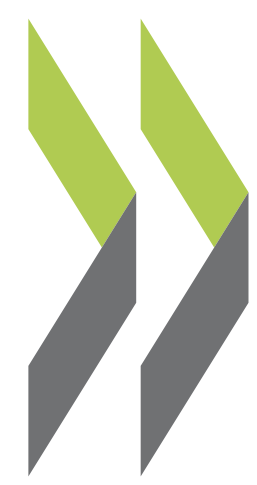

OECD Economics Department Working Papers No. 499

\title{
Improving Public-spending Efficiency in Czech Regions and Municipalities
} Philip Hemmings 
Organisation de Coopération et de Développement Economiques

Organisation for Economic Co-operation and Development

18-Jul-2006

ECONOMICS DEPARTMENT

English text only

IMPROVING PUBLIC-SPENDING EFFICIENCY IN CZECH REGIONS AND MUNICIPALITIES ECONOMICS DEPARTMENT WORKING PAPERS NO. 499

by

Philip Hemmings

All Economics Department Working Papers are available through OECD's website at www.oecd.org/eco/working_papers 


\section{ABSTRACT/RÉSUMÉ}

\section{Improving public-spending efficiency in Czech regions and municipalities}

This paper looks at ways of ensuring Czech regions and municipalities are fully motivated to make efficiency improvements in public service provision and so help achieve countrywide fiscal sustainability. The very large number of small municipalities in the Czech Republic means that scale economies are difficult to exploit and the policy options for overcoming this problem are discussed. In the financing system there are issues of transparency and the balance between autonomy for the regions and municipalities and central-government power to direct resources. In terms of accountability, questions of oversight and transparency arise in the public-procurement system and benchmarking in cost and output in public services is not yet widely used.

This Working Paper relates to the 2006 OECD Economic Survey of the Czech Republic (www.oecd.org/eco/surveys/Czech).

JEL codes: $\mathrm{H} 50, \mathrm{H} 70$

Keywords: Czech Republic; regions; municipalities; public expenditure.

\section{L'amélioration de l'efficience des dépenses publiques dans les régions et les communes en République tchèque}

Ce document porte sur les moyens de veiller à ce que les régions et communes tchèques soient pleinement encouragées à réaliser des gains d'efficience dans la prestation des services publics, et à contribuer ainsi à garantir la viabilité budgétaire de l'ensemble du pays. Le très grand nombre de petites communes que compte la République tchèque signifie que les possibilités d'économies d'échelle sont difficiles à exploiter, et les options envisageables pour résoudre ce problème sont examinées. Par ailleurs, le système de financement soulève des questions de transparence et d'équilibre entre l'autonomie des régions et des communes, d'une part, et les prérogatives de l'administration centrale en matière de répartition des ressources, d'autre part. En termes d'obligations redditionnelles, des questions de contrôle et de transparence se posent dans le domaine des marchés publics, et l'analyse comparative des coûts et des résultats reste peu utilisée dans les services publics.

Ce Document de travail se rapporte à l'Étude économique de l'OCDE de la République tchèque 2006 (www.oecd.org/eco/etudes/tcheque).

Classification $\mathrm{H} 50, \mathrm{H} 70$

Mots clés : République tchèque ; régions ; communes ; dépenses publiques.

Copyright (C) OECD, 2006

Application for permission to reproduce or translate all, or part of, this material should be made to: Head of Publications Service, OECD, 2 rue André-Pascal, 75775 PARIS CEDEX 16, France. 


\section{TABLE OF CONTENTS}

Improving public-spending efficiency in Czech regions and municipalities............................................ 4

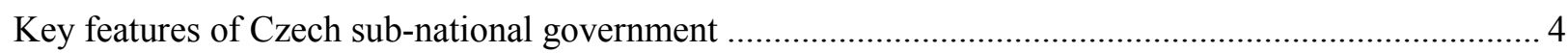

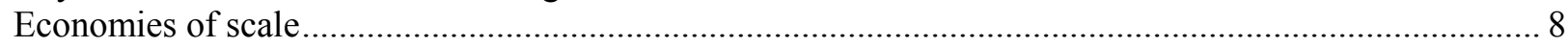

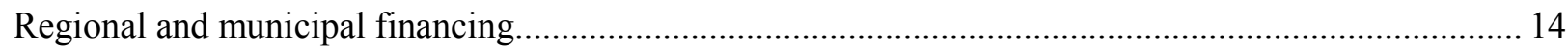

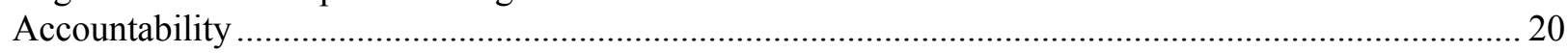

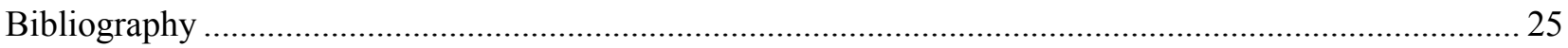

Annex 1 Incentives for municipalities to merge in the tax-allocation system........................................... 26

Annex 2 The structure of municipalities' delegated powers ...................................................................... 28

\section{Boxes}

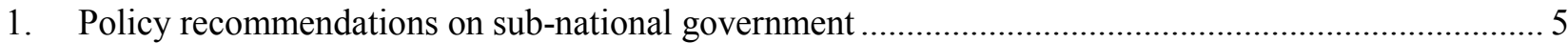

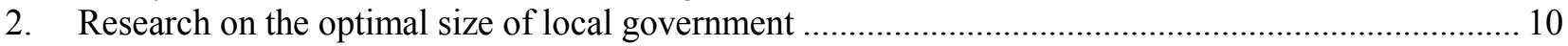

3. OECD experiences in mergers of municipal government ….............................................................. 12

4. Regional financing of hospitals: the debate on corporatisation .................................................... 19

5. Examples of abuses and violations of Czech public procurement rules ............................................. 21

\section{Tables}

1. The assignment of "independent competencies" and "delegated powers" ........................................... 7

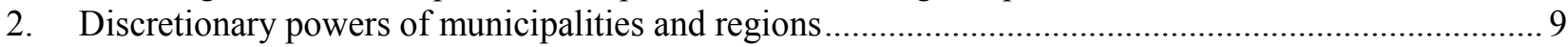

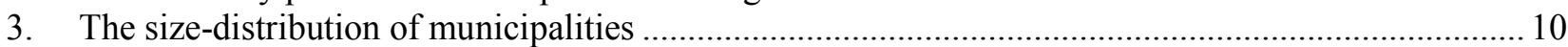

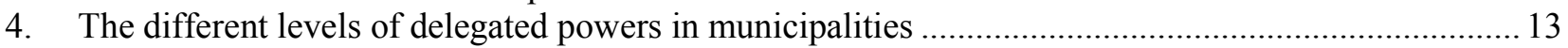

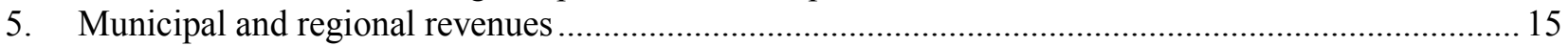

6. Revenues and expenditures of municipalities and regions (2005).................................................. 16

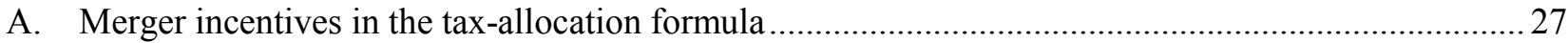

\section{Figures}

1. Sub-national governments' shares in general government expenditure ............................................... 6

2. The structure of public administration in the Czech Republic......................................................... 7

3. International comparison of the average number of inhabitants per municipality.............................. 10

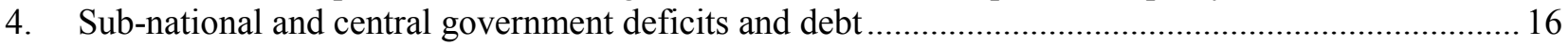

5. Sub-national government revenue from grants and taxes ................................................................ 20 


\title{
IMPROVING PUBLIC-SPENDING EFFICIENCY IN CZECH REGIONS AND MUNICIPALITIES
}

\author{
By \\ Philip Hemmings ${ }^{1}$
}

1. Achieving fiscal sustainability in public spending requires concerted reform efforts, not only by central government ministries and agencies but also by municipal and regional governments. In many key areas of spending, central government initiatives for improved service delivery can only be effective if subnational governments are willing participants in the reform process. In addition, regions and municipalities have to be motivated to initiate spending reforms of their own because many potential improvements in service provision can only be seen by those working directly with providers.

2. This paper first looks at the structure and responsibilities of Czech sub-national government. This is followed by detailed analysis under three headings: economies of scale; regional and municipal financing; and, accountability. The policy recommendations are summarised in Box 1.

\section{Key features of Czech sub-national government}

3. Municipal self-governments were established in the early 1990s with boundaries typically following those of previous local administrative units. In 2000 there was further decentralisation of government with the establishment of 14 regional governments and the termination of a network of 76 administrative districts (okresy), which had no directly elected representatives. ${ }^{2}$ In terms of the share of total public spending, Czech sub-national government is not exceptional. The regions and municipalities together account for about $30 \%$ of general government spending, a similar level to Austria, Poland Norway and Italy (Figure 1). However, the system is exceptional in terms of the number of sub-national governments. There are 6243 municipalities (obce) and their populations vary in size enormously, raising questions as to whether economies-of-scale are fully exploited (see below). The regions (kraje) range in population from 300000 to 1.3 million. This level of government is also relatively small-scale in the sense that most of the regions are not big enough to qualify as "NUTS2" regions for EU-regional funding purposes.

1. The author is an economist in the Economics Department at the OECD. This paper draws on material originally produced for the OECD Economic Survey of the Czech Republic published in June 2006 under the responsibility of the Economic and Development Review Committee. Thanks are due to experts from the Czech Ministries of Interior and Finance, in particular Lubomir Chaloupka and Irena Rehova. The author would also like to thank OECD colleagues Andrew Dean, Alessandro Goglio, Val Koromzay and Andreas Wörgötter for comments as well as Margaret Morgan for statistical assistance.

2. Legislation creating the regions was passed in 1997 but they were not set up until 2000. The regions did not effectively begin operating until 2001 after the first regional elections were held. The former districts did not have directly elected representatives but there were district assemblies comprising of representative from municipalities. The city of Prague (which has over $10 \%$ of the population) has a special status in the system, being both a municipality and a region. Useful description of local-government structures can be found in Ministry of Interior (2004) and OECD (2004). Interesting comparisons in systems of intergovernmental relations across the EU-8 countries can be found in World Bank (2005). 


\section{Box 1. Policy recommendations on sub-national government}

Opportunities to encourage greater economies of scale in service provision have to be fully exploited:

- Further strengthening of incentives for municipalities to merge should be explored. In particular: further steepening of the tax allocation schedule, one-off compensation to cover the costs of mergers and the removal of biases in grant formulae that favour support small-scale operations.

- The authorities should also explore ways of encouraging more co-operation in the provision of independent competencies. In particular, the proposal to alter tax allocation rules to benefit municipalities who sign cooperation agreements looks promising and should be developed further.

- Exploit the potential for rationalising the networks of offices providing central-government services ("delegated powers"). Particular attention needs to be paid to the municipalities of extended scope.

- While the fact that most regions are below NUTS2 level certainly does not warrant an immediate reconsideration of regional boundaries, this should be taken into account if debate on the regional structure is re-opened.

Adjustment of sub-national government financing to further increase transparency and provide the right balance between autonomy for the regions and municipalities and central-government power is needed:

- Some tightening of the debt rules is required: the sanctions are rather soft and the inclusion of debt repayment in "debt servicing" is problematic.

- Various measures should be taken to improve transparency, notably: further development of the Ministry of Finance's on-line "ARIS" database of regional and municipal accounts and widening the legal powers of the Supreme Audit Office to allow full audits of municipalities.

- A close eye should be kept on the use of private-sector audits by the municipalities.

- $\quad$ The broad thrust of policy should be towards more flexibility in the use of grant revenue. However is needed caution because some spending areas are due major system-wide reform and cost and output indicators have yet to reach a satisfactory stage of development.

- At the same time, some more room for regions and municipalities in discretionary taxation is warranted. One solution, for example, would be to widen the scope for setting real-estate taxation.

Improvements in accountability are needed along the following lines:

- Oversight and transparency in public procurement need to be strengthened. Prague has taken a welcome lead in going beyond legal requirements by publishing details of all its procurement contracts on line; other jurisdictions should be encourage to follow this example.

- In cost and output benchmarking, additional incentives to encourage participation are needed if benchmarking projects are to mature into comprehensive nationwide systems.

- In e-government, the set-up cost for users of electronic signatures needs to be brought down. Better coordination between some government databases is needed to cut back on red tape, particularly for businesses. 
Figure 1. Sub-national governments' shares in general government expenditure Per cent

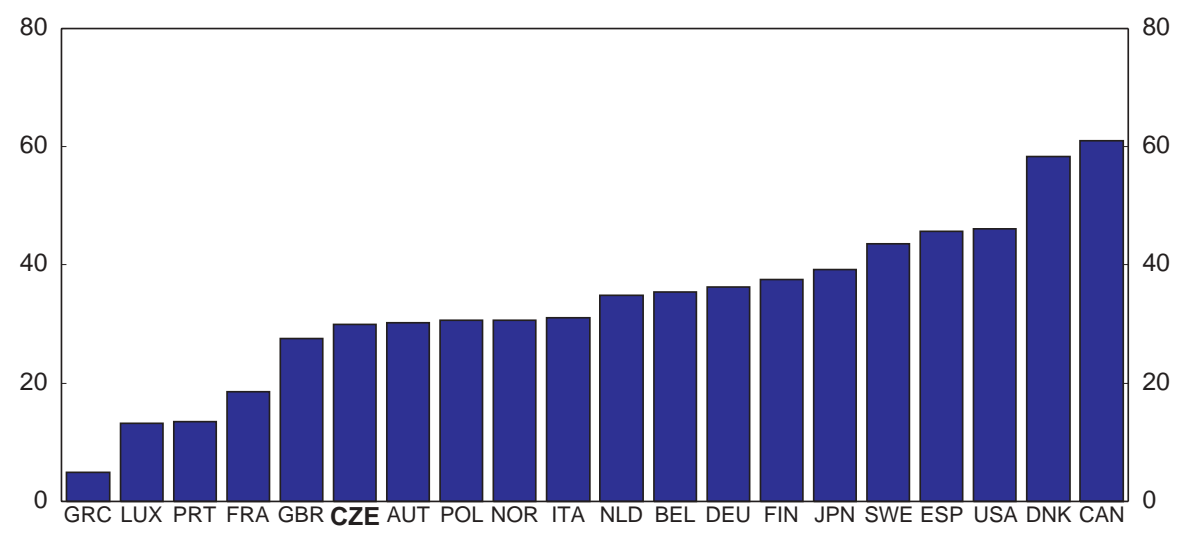

Source: Secretariat estimates based on the latest available national accounts figures (2003 for most countries). For the Czech Republic, regional and municipal accounts for 2004 have been used.

4. A fundamental distinction is made in the Czech system between "independent competencies" and "delegated powers". For independent competencies, sub-national governments have strong legal rights of self-determination. Indeed, the independent competencies are a key raison d'etre for regional and municipal government as these responsibilities are where, at least in theory, local democracy has its say on policy. For municipalities the most important independent competencies in terms of spending are primary health care, primary school education, public housing and local roads (Table 1). The decentralisation process notably involved passing responsibility for general hospitals and secondary-school education from central government to the regions.

5. For delegated powers, the municipalities and regions are in a legal sense the executors of centralgovernment policy and therefore, in principle, have much less influence on policy. In the decentralisation of the early $2000 \mathrm{~s}$ delegated powers were increased. About $80 \%$ of the tasks carried out by the administrative districts (okresy) were passed on to municipalities, mostly to a specially formed group of 205 "municipalities of extended scope". The remaining tasks were allocated mainly to the regions. ${ }^{3}$ However, some important networks of local offices remain directly managed by ministries and other central government bodies (Figure 2). Indeed the labour offices, which are run by the Ministry of Labour and Social Affairs, have been given increased responsibilities. In 2004, the administration of state social support (including the means-tested "minimum living allowance") was transferred from municipal offices to the labour offices. It should also be noted that the municipalities of extended scope are only one layer in a rather complex structure of municipality networks, this is discussed further below.

3. Some relatively minor tasks carried out by the former districts were allocated to the central government. 
Table 1. The assignment of "independent competencies" and "delegated powers"1

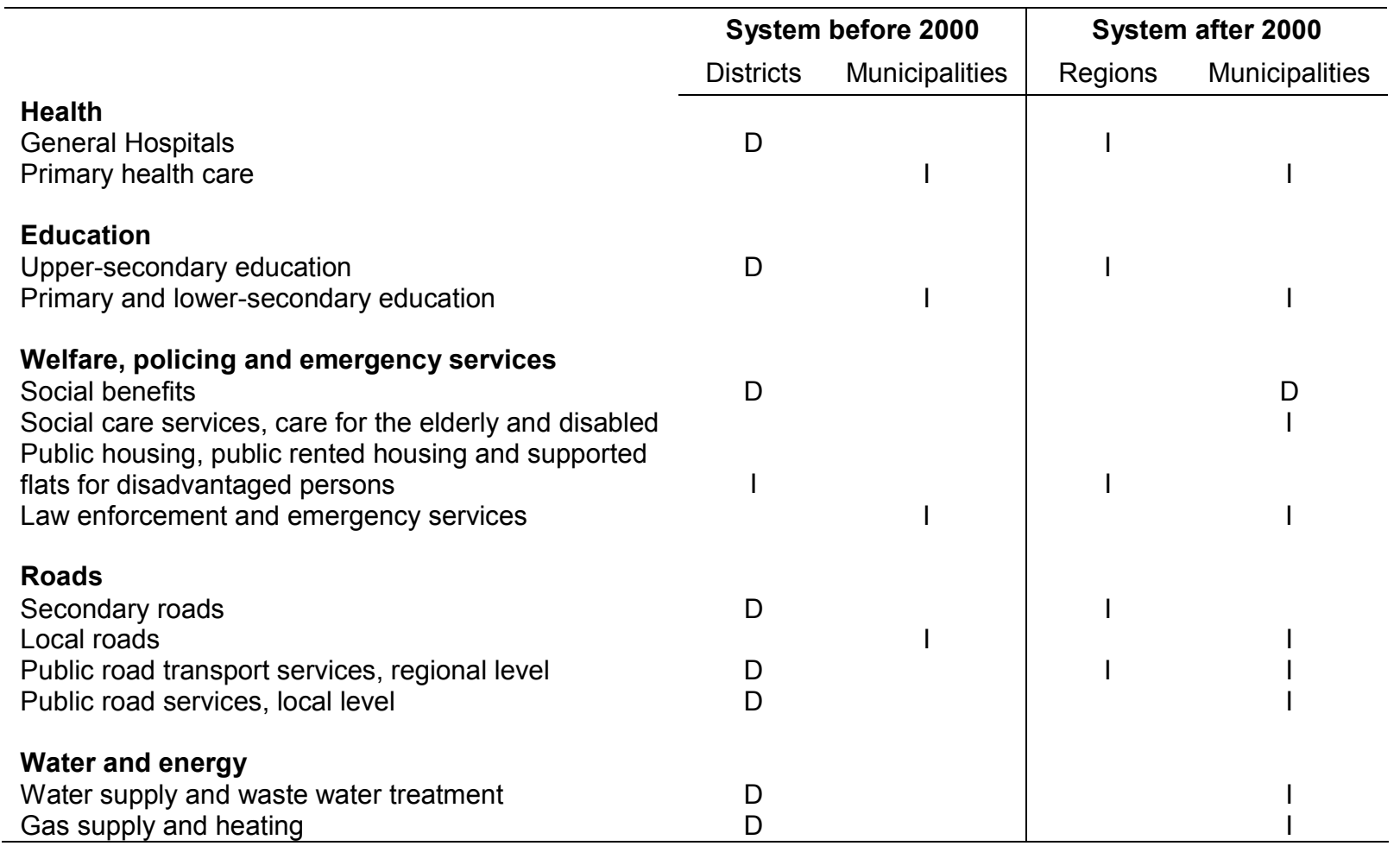

Note: I: Activities classified as "independent competencies" in municipalities and regions. The Districts only had delegated powers. D: Activities classified as "delegated powers" in municipalities, regional government and (previously) districts.

1. Only the most important activities (in terms of spending) are listed in the table. Other independent responsibilities and delegated powers include culture and recreation and various administrative services such as issuing identity papers and driving licences.

Source: OECD, based on information from the Ministry of Interior.

Figure 2. The structure of public administration in the Czech Republic

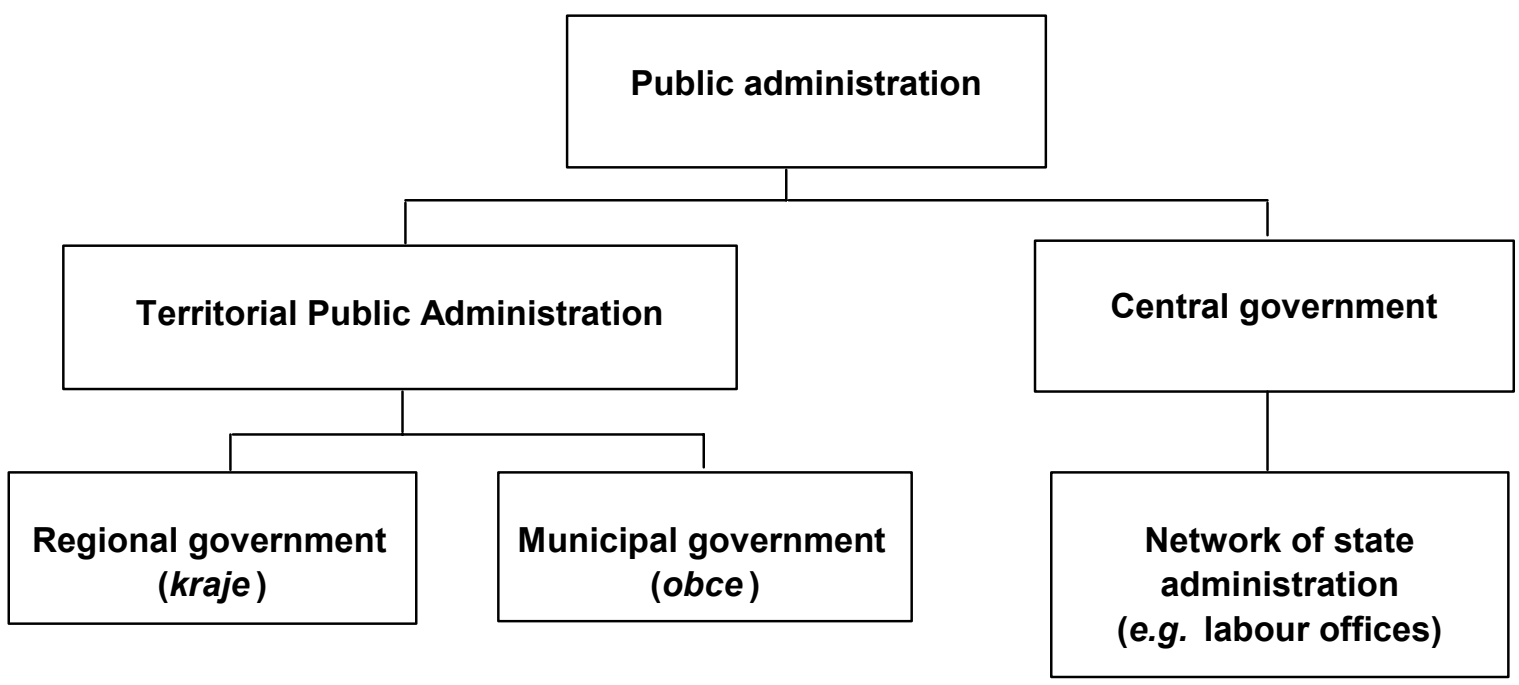


6. Czech sub-national government initiates a lot of public investment. Some arises from obligations in independent competencies, in particular local roads, water services and energy supply. Other investment activity is of a more voluntary nature (i.e. it is not related to legally assigned responsibilities). Development projects, such as technology parks, are common among the regions and larger municipalities. Indeed, most investment projects of this kind are initiated by sub-national government and this decentralised process is important when, for instance, assessing R\&D policy. The projects often involve co-operation and close ties between the local authority, the business community and local institutions, such as universities. For example, a municipality might set up a subsidised company to build a technology park, get further financial backing from investors and involve the local university to help raise the attractiveness of the park to high-tech companies. The municipalities often co-operate in such projects.

7. The balance of power between sub-national and central government in policymaking is of course affected by other factors besides legal distinctions between responsibilities. These are summarised for different areas of public spending in Table 2. The freedom in policymaking that independent competency implies is contained in several ways. Service standards and earmarked grants define minimum standards and minimum levels of spending. Also for both administration and public services, employees must typically be paid according to nationally negotiated pay agreements. For delegated powers, key features of the services are set but there is freedom in how systems are administered - the grants provided are not earmarked.

\section{Economies of scale}

\section{Small municipalities: what are the options for scaling up service provision?}

8. Reducing the risk of high costs and compromised service quality in small municipalities needs to be a key focus of efforts to improve the efficiency of the sub-national government. The average size of Czech municipalities is one of the lowest in the EU (Figure 3) reflecting numerous very small units. For instance, around 2500 municipalities have populations of less than 300 (Table 3). This being said, there is a fair amount of combined service provision. Most delegated powers are typically assigned to subnetworks of municipalities (in particular the municipalities of extended scope). Also many municipalities co-operate in providing independent competencies. About $40 \%$ of all municipalities are members of one of 470 official voluntary associations of municipalities (dobrovolné svazky obci), these are recognised legal entities and can be a vehicle for providing a wide range of public services. Despite these considerations, many of the very small municipalities are likely to struggle with the basic administrational overheads in running local government and in organising even a simple range of public services. Indeed, research on scale economies in Swiss local government (a system often held up as a case where small-scale government works well) suggests that a large share of Czech municipalities are below a critical minimum size in terms of efficiency (See Box 2). 
ECO/WKP(2006)27

Table 2. Discretionary powers of municipalities and regions

\begin{tabular}{|c|c|c|}
\hline Public service & $\begin{array}{l}\text { Key aspects of the service set } \\
\text { by central government }\end{array}$ & Key areas of discretionary power \\
\hline \multicolumn{3}{|l|}{ Regional government } \\
\hline Administration & $\begin{array}{l}\text { Pay scales of administrators and of elected } \\
\text { representatives. }\end{array}$ & Staffing levels. \\
\hline Regional hospitals & $\begin{array}{l}\text { Detailed specification of treatment covered by } \\
\text { the public system. } \\
\text { Influence on funding via role in setting amount } \\
\text { that insurance funds must pay for hospital } \\
\text { care (see main text). Also influence through } \\
\text { grants for large investment projects (e.g. new } \\
\text { hospitals). } \\
\text { Influence via role in setting nation-wide pay } \\
\text { increases for a large share of health care } \\
\text { workers. }\end{array}$ & $\begin{array}{l}\text { Hospitals that have been converted to } \\
\text { regionally-owned enterprises have more } \\
\text { discretion on pay. }\end{array}$ \\
\hline Upper secondary education & $\begin{array}{l}\text { Regions must submit education development } \\
\text { plans consistent with national strategy. } \\
\text { Influence via per-capita financing for current } \\
\text { expenditures and grants for buildings } \\
\text { Direct setting of some parts of the curriculum } \\
\text { and final examination. } \\
\text { Conditions of teacher service (qualification, } \\
\text { duties and pay scales). }\end{array}$ & $\begin{array}{l}\text { Discretion on staffing levels and opening and } \\
\text { closing down facilities. } \\
\text { Human resources management (largely } \\
\text { delegated to school heads). } \\
\text { Discretion on some parts of the curriculum } \\
\text { and in setting some parts of the final exam. }\end{array}$ \\
\hline Secondary roads & Technical standards. & $\begin{array}{l}\text { Full discretion, though approval and co- } \\
\text { ordination with other levels of government is } \\
\text { important. }\end{array}$ \\
\hline $\begin{array}{l}\text { Municipal government } \\
\text { General administration }\end{array}$ & $\begin{array}{l}\text { Pay scales of administrators and of elected } \\
\text { representatives. }\end{array}$ & Staffing levels. \\
\hline Primary health care & Similar to regional hospital services. & Similar to regional hospital services. \\
\hline $\begin{array}{l}\text { "Basic" education (i.e. primary + } \\
\text { lower secondary) }\end{array}$ & $\begin{array}{l}\text { Municipalities must submit education } \\
\text { development plans consistent with national } \\
\text { strategy. } \\
\text { Influence via per-capita financing for current } \\
\text { expenditure and grants for building. } \\
\text { Sets the standardised tests taken at the end of } \\
\text { primary and secondary education. } \\
\text { Conditions of teacher service (qualification, } \\
\text { duties and pay scheme). }\end{array}$ & $\begin{array}{l}\text { Education Development Plans for the region } \\
\text { (to comply to the national plan). } \\
\text { Establishing, maintaining and steering basic } \\
\text { schools, modifications in their network (of } \\
\text { their number, site and location). } \\
\text { Human resources management (largely } \\
\text { delegated to school heads). }\end{array}$ \\
\hline $\begin{array}{l}\text { Public housing } \\
\text { Refuse collection and processing } \\
\text { Local public transport } \\
\text { Water supply and waste water } \\
\text { Gas supply and heating } \\
\text { Local public transport }\end{array}$ & $\begin{array}{l}\text { Technical standards (and sometimes approval } \\
\text { requirements, e.g. when constructing a water } \\
\text { or gas pipeline). }\end{array}$ & $\begin{array}{l}\text { Full discretion on level and quality of service } \\
\text { (subject to standards and, where applicable, } \\
\text { approval). Co-ordination and joint provision } \\
\text { is common among small municipalities. }\end{array}$ \\
\hline $\begin{array}{l}\text { Social benefits, social care } \\
\text { services, care for the elderly and } \\
\text { disabled (administered by } \\
\text { municipalities of extended scope) }\end{array}$ & $\begin{array}{l}\text { All aspects of the benefit systems are set by } \\
\text { central government. }\end{array}$ & $\begin{array}{l}\text { Complete freedom how policies are } \\
\text { administered (number of offices, staffing } \\
\text { levels etc). Transfers from central } \\
\text { government to cover administration costs are } \\
\text { not earmarked. }\end{array}$ \\
\hline $\begin{array}{l}\text { "Municipal offices", building } \\
\text { permits, and registry offices }\end{array}$ & $\begin{array}{l}\text { All legal and technical issues are set by } \\
\text { central government. }\end{array}$ & As above. \\
\hline
\end{tabular}

1. The provision of public housing is only one aspect of housing policy. Municipalities also administer support for rentals provided in the social welfare system, however they are not involved in mortgage support schemes.

Source: OECD assessment based on various information from the Czech authorities. 
Figure 3. International comparison of the average number of inhabitants per municipality Thousands

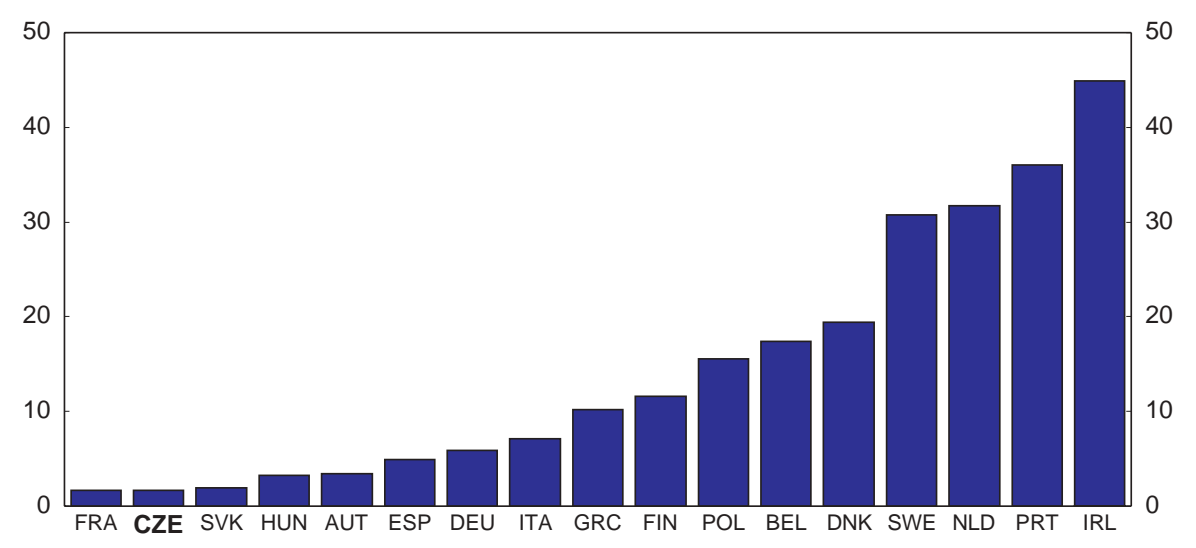

Source: Dexia Bank.

Table 3. The size-distribution of municipalities

\begin{tabular}{|c|c|c|c|c|}
\hline Population range & $\begin{array}{c}\text { Number of } \\
\text { municipalities }\end{array}$ & $\begin{array}{c}\text { Number of municipalities } \\
\text { (cumulative) }\end{array}$ & $\%$ of total population & $\begin{array}{c}\% \text { of total population } \\
\text { (cumulative) }\end{array}$ \\
\hline $0-100$ & 557 & 557 & 0.4 & 0.4 \\
\hline $101-200$ & 1086 & 1643 & 1.6 & 2.0 \\
\hline $201-300$ & 890 & 2533 & 2.1 & 4.1 \\
\hline $301-1500$ & 2850 & 5383 & 18.4 & 22.5 \\
\hline $1501-5000$ & 592 & 5975 & 14.8 & 37.3 \\
\hline $5001-10000$ & 137 & 6112 & 9.1 & 46.4 \\
\hline $10001-20000$ & 68 & 6180 & 9.3 & 55.8 \\
\hline $20001-30000$ & 28 & 6208 & 6.8 & 62.6 \\
\hline $30001-40000$ & 9 & 6217 & 3.1 & 65.7 \\
\hline $40001-50000$ & 5 & 6222 & 2.3 & 68.0 \\
\hline $50001-100000$ & 16 & 6238 & 11.3 & 79.3 \\
\hline $100001-150000$ & 1 & 6239 & 1.0 & 80.3 \\
\hline 150 000+ (excl. Prague) & 3 & 6242 & 8.2 & 88.5 \\
\hline Prague & 1 & 6243 & 11.5 & 100.0 \\
\hline
\end{tabular}

Source: Ministry of Finance.

\section{Box 2. Research on the optimal size of local government}

It is difficult to draw many general conclusions about the optimal size of local government from the available evidence. This is largely because context matters tremendously. The optimal size of units depends a lot on which services local governments provide and the incentives for (and the efficiency of) co-operative provision. It is self evident, for instance, that if local government is responsible for hospital services, it should be on a bigger scale than if it is only responsible for ensuring general practitioners' services. However, there is reasonably broad agreement among experts that there is some point at which the small size of the municipality means higher costs (or compromised service quality) for virtually all public services. Research of small local governments in Swiss Cantons suggests that costs and quality are severely compromised below a population of 500 . Indeed, recent jurisdictional reforms in some areas of Switzerland have focused on municipalities below 500 and some cantons are aiming at a threshold of at least 3000 (Ladner et al. 2003). Well over half of Czech municipalities' populations are below 500. 
9. The most obvious solution to the Czech problems of economies of scale is for the small municipalities to merge. However, this is easier said than done. For fundamental constitutional reasons, central government cannot unilaterally decree the merger of municipalities and policy has to work more indirectly through mechanisms altering financial incentives.

10. Changes to the municipalities' tax allocation formula in 2001 introduced some incentives to merge, though more by consequence than design. The revised formula was based on the existing tax allocation and this implied giving progressively larger per-capita payments with increasing municipality size. Per-capita tax allocations in other countries are typically either flat or U-shaped in relation to the size of local government, so the Czech system is indeed somewhat unique in providing incentives to merge among small units. However, so far, no mergers have taken place following the change in formula. ${ }^{4}$ Municipalities are perhaps taking time to respond to the incentives, but it is also likely that the potential gains are not sufficiently attractive. Prima facie it appears that some municipalities have a lot to gain from merging; indeed it is possible to construct scenarios where municipalities could get as much as $40 \%$ higher tax revenue. However, the potential number of such scenarios is quite limited and tax revenues anyway typically only account for about one-quarter of total revenue, so even in the most advantageous merger scenarios municipalities would only gain about $10 \%$ more revenue (see Annex A1 for further discussion).

11. Further strengthening of incentives for municipalities to merge should be explored. In particular:

- Steepening of the tax allocation schedule for the smallest municipalities. However, a weather eye would have to be kept on the cost implications, as agreement between central and sub-national governments on such a move would probably involve increasing the overall level of tax allowances. ${ }^{5}$

- One-off compensation to cover the costs of mergers. The Finns, for instance, have had some success in inducing local-government mergers through one-off compensation (see Box 3). Arguably, a one-off payment is preferable to schemes that manipulate the tax allocation because the cost of encouraging the mergers is clearer.

- Removal of biases in grant formulae that favour small-scale operations. Measures of this sort have had some success in Switzerland where the removal of biases in funding has motivated some municipality mergers. However, once again agreement on this is unlikely without at least some additional short-term costs for central government.

12. However, incentives for municipalities to merge cannot be counted on. First, it may prove politically impossible to introduce them. The difficulty of making reforms in local-government finance is illustrated by on-going efforts to reach agreement on changing the tax-allocation formula from a stepped schedule to a smooth function. ${ }^{6}$ Political constraints are common elsewhere; the examples of successful

4. The new tax allocation system for municipalities used the distribution of revenues in 1999 (that was based on the previous multi-dimensional formula) as a starting point for setting the per-capita allocations. The new formula resulted in about three-quarters of municipalities getting more revenue and about one quarter less.

5. It is unlikely the municipalities would agree a reform of the tax allocation schedule that involved reducing the tax allocation for any significant number of municipalities. Therefore, any steepening of the schedule would probably involve a larger overall tax allocation.

6. The tax allocation formula for municipalities gives different per-capita amounts according to different ranges of population. This stepped schedule has the advantage of simplicity but it also has weaknesses. For a start, there are issues of fairness. For instance, a municipality whose population falls slightly short of the next size category is in a sense getting a bad deal out of the system. In addition, the formula has prompted 
measures in Box 3 are encouraging, but they are also rare. Second, international evidence suggests that the returns to mergers go mainly to the local population in the form of better quality public services and that fiscal savings are at best only realised in the long term (see Box 6).

\section{Box 3. OECD experiences in mergers of municipal government}

The Czech Republic is not alone in having small municipalities that are strongly resistant to measures imposing or encouraging mergers. For instance, expert assessment of Norwegian and French local government also often concludes that the system would work better if it had larger municipalities, but there are seemingly few practical ways of making headway in policy.

However, in one or two countries central government has succeeded in persuading mergers. In Finland, where similar to the Czech Republic municipalities are protected by strong constitutional rights, a system of grants has provoked some mergers. ${ }^{1}$ In Denmark central government also offered one-off transfers designated as covering the costs of merging but this was also combined with a threat to re-draw municipal borders unless the municipalities themselves organized mergers. In Japan, the removal of favourable biases in grants was combined with rules allowing expanded municipal councils if municipalities merged. Some mergers in Switzerland have also been prompted by the removal of biases in grant funding.

Research on the impact of mergers often finds evidence of improved service quality but rarely finds evidence of significant cost savings. For example, case study evidence suggests that efficiency gains are used to increase service quality rather than to reduce expenditure. In part this is because measures used to encourage mergers typically involve giving local authorities more resources and the incentives for costcutting can therefore be low. In addition, savings in costs can take a long time to implement. Staffing cuts are a sensitive issue in mergers and might only happen over the long run through non-replacement of staff who retire.

1. Three types of grant are available in Finland to encourage municipalities to merge: grants based on population size, grants to compensate any losses in equalisation payments from merging and special investment and development grants. The system was introduced in the late 1990s.

13. Avenues for encouraging more co-operation in the provision of independent competencies should be explored. Again, tax allocation could be a useful instrument. Indeed, a proposal along these lines has already been developed by the Ministry of Interior. In this proposal, municipalities would make explicit agreements to co-operate in the provision across an agreed range of services and the tax allocation (based on the current stepped system) would be calculated on the combined population of the municipalities involved. ${ }^{7}$ The scheme looks promising, though some aspects of it need careful consideration. First, there will be some deadweight loss because municipalities that already co-operate will benefit. Second, it might

some undesirable schemes to push municipality populations into higher population brackets. For example, one municipality has targeted transient households with cash offers to register as residents. Alternatives to the stepped schedule have been sought for some time, in particular a smooth schedule in which per-capita allocation increases incrementally with population size. However, agreement between the various stakeholders is not easy. It is very difficult to find a smooth schedule that does not reduce the tax allocation for at least some municipalities (something that they understandably resist) without increasing the overall tax allocation.

7. The proposal in its current form also includes some delegated competencies in the list of services that could be included in the scheme. 
prove tricky to ensure the co-operation agreements result in concrete economies in service provision and not just superficial organisational changes. Finally, as with schemes to promote mergers, the returns from a fiscal perspective may be limited because the efficiency gains are more likely to emerge in improved service quality rather than cost savings.

14. Another route would be to exploit the potential for rationalising the networks of offices providing state administration (i.e. delegated powers). The administrative structure of delegated powers has evolved into a quite complex system. In addition to the municipalities of extended scope (obecní úrady s rozšírenou puisobnosti) there is a network of 388 "municipalities of the second type" (pověrene obenci úrady) (see Table 4 and Annex A2). There are also more extensive networks of offices that run population and building registers. The piecemeal development of the system almost certainly means it is overly complex. It is also likely that rationalisation in the networks of offices has not fully kept pace with increases in mobility and developments in communication, such as e-government (see below). Some adjustment of the subsidies given to municipalities for carrying out state administration was made recently following investigation of costs in service provision. ${ }^{8}$ However, the reform focussed on ironing out inequalities in allocation and not on the efficiency of structures as a whole. A broader examination of efficiency should be conducted with a view to rationalisation of the networks of offices. Particular attention needs to be paid to the municipalities of extended scope. The allocation of many of the services provided by the 76 former districts to these 205 municipalities was in broad terms a backwards step in terms of scale economies. Indeed some of these municipalities are reportedly struggling to fulfil their service obligations.

Table 4. The different levels of delegated powers in municipalities

\begin{tabular}{lc}
\hline Type of municipality & $\begin{array}{c}\text { Number of } \\
\text { municipalities }\end{array}$ \\
\hline Basic delegated powers (e.g. emergency management) & 6243 \\
Municipalities running population registration & 1226 \\
Municipalities providing building permits & 617 \\
Municipalities of the "second type" (pověřené obecní úřady, see Annex A2) & 388 \\
Municipalities of extended scope or "third type" (obecní úr̆ady s rozšířenou působností or & 205 \\
malé okresy). These were formed after the break up of the districts. Roughly 80\% of the \\
former district services were passed on to these municipalities, the remainder to the regions. \\
See Annex A2.
\end{tabular}

1. There is no definitive structure for the more minor delegated powers and no strict hierarchy. For example some municipalities with building permit offices do not run the population register. The geographic boundaries of the networks of smaller services do not necessarily line up with those of the municipalities of second type and municipalities of extended scope.

Source: Ministry of Interior.

8. The municipalities were initially compensated in two ways for taking over administrative services of the former districts. Special additional per-capita payments were made for providing services. Municipalities of extended scope were also compensated for each employee transferred from district to municipal offices. The system however was criticised having extremely uneven rates of compensation, particularly between the municipalities of extended scope and other municipalities and, following investigation by a working group into the costs of services, a new compensation system began operating in 2006. The employee compensation has been scrapped and compensation is based on a per capita approach, though with some complications. Notably those municipalities who stand to loose more than $2 \%$ of subsidy under the new system are eligible for additional subsidy and Prague's compensation continues to operate on a slightly different basis. 


\section{The regions: most are too small to administer $E U$ funding}

15. The establishment of the regions was partly motivated by the need for an interface for EU structural funds. ${ }^{9}$ The EU regional funding system requires regional units with populations between 0.8 and 3 million (the NUTS2 level of regional disaggregation). However, several of the 14 regions do not fulfil these criteria and combinations of regions have been formed for EU funding purposes. ${ }^{10}$ Indeed, only three regions are stand-alone EU-funding units. To some extent this only has statistical implications but it also complicates regional administration and policymaking. While this issue does not warrant urgent reconsideration of regional boundaries, it should be taken into account if debate on the regional structure is re-opened in the future, particularly if co-operation between regions on EU issues proves difficult.

\section{Regional and municipal financing}

16. As in other countries, the system of financing regions and municipalities has a strong influence on the de facto level of self-determination in the regions and municipalities. In this respect, the key features of the Czech system are as follows:

- Most of the tax revenue is via a formula-based allocation of personal income tax, corporate income tax and value-added tax (Tables 5 and 6). As described above, for municipalities, the allocation is a per-capita payment based on population size. The allocation is $20.59 \%$ of the base. When the regions were first established the tax allocation was initially $3.1 \%$ of the tax base but was raised to $8.92 \%$ in 2005 (with offsetting cuts in grants). The regional funding formula combines population size with several other criteria including land area, size of road network and the number of school pupils. In municipalities, a small share of the total tax allocation is based on local incomes of the self employed and the employed. In addition, there is some leeway for local revenue through real-estate taxes (though within statutory limits) and fees. In contrast, the regions have no revenue linked to their tax base, nor any revenues from local fees.

- Grants are generally earmarked (i.e. provided for a specific purpose and accompanied by monitoring systems) and require matching funding. Grants for current expenditures are formulabased while capital grants are allocated using a more case-by-case approach. A grant is provided to cover the cost of providing central-government services (including those transferred to the regions and municipalities following the dissolution of the districts) but unlike most other grants it is not earmarked. Since 2005, the central government grant for teachers' wages and some other

9. Commitment to forming the regions has been long standing. The Czech constitution that came into force in 1993 contained a clause that another layer of government would be introduced, though with no specification of terms or on when this would happen.

10. The EU regional funding system is based on geographical units according to Eurostat's "NUTS" system which comprises several levels of geographic disaggregation. NUTS2 is the main basis of the funding system with economic conditions in NUTS2 regions determining whether the region is eligible for support from regional funds. The fourteen regions are combined into eight NUTS2 units for EU-funding purposes as follows: Plzeňský and Jihočeský form the Southwest unit, Karlovarský and Ústecký form the Northwest unit, Liberecký, Královéhradecký and Pardubický regions form the Northeast unit, Vysočina and Jihomoravský form the Southeast unit, Olomoucký and Zlínský constitute form the Central Moravia unit. Prague, Central Bohemia and the Moravian Silesian regions are stand-alone units. Prague is the only NUTS2 not to be eligible for funding. 
education grants no longer passes through the municipalities books. ${ }^{11}$ As a result by far the largest grants to municipalities are for providing the various forms of municipal social assistance.

- Municipalities and regions otherwise have a reasonably free hand in financing, but there are rules and possible sanctions. Annual budgets submitted to the authorities have to balance and there is some regulation on debt (more on this below). Private-sector bank credit is used by many municipalities, some large municipalities issue bonds and institutional lending, notably by the European Investment Bank, is becoming more important (particularly for regions). Funding opportunities via EU co-financed projects is also set to become more important. Money is also raised through sales of assets and flows from off-budget accounts also play a role.

\section{Table 5. Municipal and regional revenues}

\begin{tabular}{|c|c|c|}
\hline & Municipalities & Regions \\
\hline \multirow[t]{4}{*}{$\begin{array}{l}\text { Tax revenue and } \\
\text { fees for services }\end{array}$} & $\begin{array}{l}21 \% \text { of aggregate PIT (simplified), CIT and VAT is distributed according } \\
\text { to a population-based formula (the per-capita amount increases with } \\
\text { size). }\end{array}$ & $\begin{array}{l}9 \% \text { of aggregate PIT (simplified), } \\
\text { CIT and VAT, distributed } \\
\text { according to a multi-criteria }\end{array}$ \\
\hline & $\begin{array}{l}30 \% \text { of incomes from personal income tax from business paid by people } \\
\text { with their permanent address in the municipality. }\end{array}$ & $\begin{array}{l}\text { area, size of road network, } \\
\text { number of school pupils). }\end{array}$ \\
\hline & $\begin{array}{l}\text { An additional } 1.5 \% \text { of PIT is distributed according to the number of } \\
\text { employees in the municipality. }\end{array}$ & \\
\hline & $\begin{array}{l}\text { Municipalities can set the rate of property tax with specified limits and } \\
\text { have discretion on various fees for services (e.g. waste disposal). }\end{array}$ & $\begin{array}{l}\text { Regions have no local-tax } \\
\text { revenue or fee income. }\end{array}$ \\
\hline \multirow[t]{4}{*}{ Grants } & $\begin{array}{l}\text { Earmarked grants for current spending. Most of the require matching } \\
\text { funding. Teachers' wages are a notable exception. }\end{array}$ & similar to municipalities \\
\hline & Non-earmarked grants to cover the cost of providing delegated powers). & similar to municipalities \\
\hline & One-off grants for investment items, such as buildings and roads. & \\
\hline & & similar to municipalities \\
\hline
\end{tabular}

Source: Ministry of Finance.

17. Municipalities typically have much more discretion over spending than regions. Untied municipal revenue in the form of tax and capital revenue accounts for over $70 \%$ of revenue, with earmarked grants accounting for the remainder according to 2005 accounts (Table 6). In contrast, a little under $40 \%$ of regional revenues are untied, though this higher than before following the change in the tax allocation from 3.1 to $8.92 \%$. However these figures only give a rough guide to the level of discretion in revenue use. In particular some tax and capital is effectively committed because it is used to provide matching funding for central-government earmarked grants.

11. In 2005, a new method of administering the central government grant for teachers' wages and some other education grants made a significant difference to municipal accounts. These grants no longer pass through the municipalities' books, thus reducing revenue and expenditure; the funds now pass from central government to regions and then to the schools (previously the funds also went via the municipalities before going to the schools). The move therefore reduced revenues and expenditures booked by municipalities and also altered the mix between grant and other revenue sources. For instance the share of tax or capital revenue and grant revenue shown in Table 3.6 for municipalities was lower prior to 2005. The estimated central government grants for 2006 illustrate the new distribution of grants to municipalities. The total value of grants is estimated to be CZK 66.6 billion; of which CZK 16 billion will be for social assistance and CZK 7 billion for state administration. Education-related grants going via municipality accounts are now relatively small at about CZK 1 billion. The change is in many respects cosmetic because the grants involved are earmarked without matching funding requirements and the municipalities' only role was to pass the money on to the schools. 
Table 6. Revenues and expenditures of municipalities and regions (2005)

\begin{tabular}{lcc}
\hline & Regions & Municipalities \\
\cline { 2 - 3 } & & \\
Revenues (\% of total revenue) & $\mathbf{3 7 . 7}$ & $\mathbf{7 3 . 0}$ \\
Tax and capital revenues & 34.9 & 57.1 \\
$\quad$ Tax revenues & 2.5 & 10.0 \\
Non-tax revenues & 0.3 & 5.9 \\
Capital revenues & $\mathbf{6 2 . 3}$ & $\mathbf{2 7 . 0}$ \\
Grant revenue (mainly earmarked) & 60.5 & 19.8 \\
$\quad$ Non-investment subsidies & 1.8 & 7.2 \\
$\quad$ Investment subsidies & & \\
Expenditures (\% of total expenditure) & $\mathbf{8 9 . 4}$ & $\mathbf{6 8 . 1}$ \\
Current expenditure & $\mathbf{1 0 . 6}$ & $\mathbf{3 1 . 9}$ \\
Capital expenditure & & \\
\hline
\end{tabular}

Note: Estimates of total revenues of regions and municipalities are CZK 113.5 billion and CZK 225.6 billion, respectively. Total expenditure of regions amount to CZK 112.6 billion and of municipalities to CZK 218.6 billion.

Source: Ministry of Finance and OECD calculations.

\section{Sub-national deficit and debt: a good track record so far}

18. The combined deficit of sub-national government has never been equivalent to more than half a per cent of GDP and regions and municipalities have accumulated only a small share of generalgovernment debt (Figure 4). Hence, neither the municipalities nor regions have, to date, collectively accounted for a disturbingly large share of general government deficit and debt. Furthermore, there have been only a handful of cases when municipalities have reached a point of financial crisis. In sum, it appears that the balanced-budget rule in combination with market discipline have been sufficient to keep subnational government deficit well within reasonable bounds.

Figure 4. Sub-national and central government deficits and debt ${ }^{1}$ Per cent of GDP
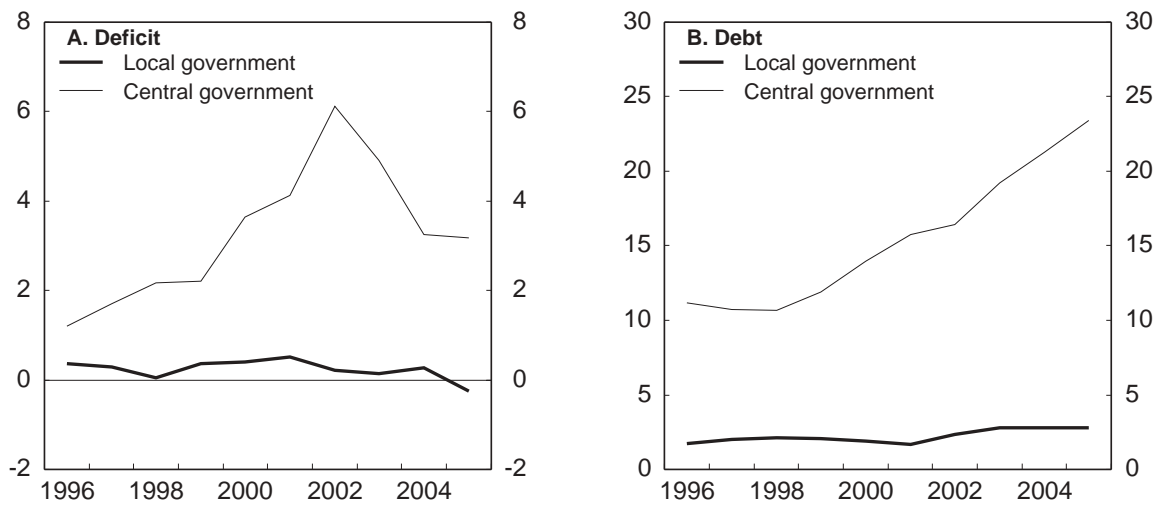

1. Data for 2005 is preliminary. Deficit data is compiled according to GFS 1986. Central government comprises state budget (including National fund), seven state funds and two privatization funds; the data cover both regions and municipalities.

Source: Secretariat calculations based on Ministry of Finance data. 
19. However, the greater opportunities for co-financed funding in the 2007-13 EU budget will be a financing challenge and may tempt some regions and municipalities into more risky revenue-raising projects. In addition, options for raising money through asset sales have already dwindled significantly. ${ }^{12}$ In response to these and other concerns, the Ministry of Finance took a number of steps in 2004 to limit the indebtedness of municipal government. In particular:

- Application for debt issues to the Securities Commission must now also be vetted by the Ministry of Finance (this was part of a new act on debentures).

- A soft capping of debt through a debt-service limit has been introduced. Regions and municipalities whose debt servicing exceeds $30 \%$ of revenue receive a formal letter from the Ministry asking for an explanation. ${ }^{13}$ At the end of 2003, a total of 211 municipalities did not fulfil the criteria and the total in 2004 was 194 . However, at least in 2004, many of these cases are known to be due to increased loan repayments (and consequently reduced indebtedness).

\section{Debt rules: a need for fine-tuning}

20. It is difficult at this stage to fully assess the effectiveness of the debt rules because the current system has only been operating a short time. However, ex-ante the system appears to have the following problems:

- The sanctions are rather soft. The strongest sanction comprises putting a municipality on a blacklist circulated to ministries and funding bodies. However, the blacklist may not have much influence on ministries' funding decisions. If this proves to be the case, the sanction should be strengthened (e.g. with explicit rules for ministries and other funding bodies on funding blacklisted municipalities) or bolstered by additional sanctions.

- Including debt repayment in "debt servicing" is problematic. The debt-servicing indicator includes debt-reducing measures such as the repayment of principal on loans. While this has the advantage of recording all payments connected with financing, it means municipalities can receive notification for good policy, such as accelerated loan repayment. The inclusion of repayment items also pushes municipalities to long-term borrowing which may not be optimal for long-term sustainability. If debt repayment were excluded this should be accompanied by a reduction in the debt-service limit because pure interest payments amounting to $30 \%$ of current revenue implies very large debt accumulation.

\section{Accounting transparency: some room for improvement}

21. Many ingredients to a healthy level of transparency in regional and municipal accounts are already in place. Both the regions and municipalities are legally bound to make their accounts available to the public, regular accounting updates are sent to the Ministry of Finance and annual audits are conducted. The auditing system was revamped in 2004 bringing stronger requirements for auditors to report on the contingent liabilities of municipalities and regions.

12. In the privatisation process the municipalities became owners of local network industries, such as water services and electricity distribution. These shares were often sold off in the late 1990s to pay for investment in these network industries. Note that Figure 3.4 does not include the privatisation revenues and so for some years the total municipal deficit on a pure cash basis would be even lower.

13. The debt service comprises paid interest, instalments of bonds, repayments of principals on loans and instalments on hire purchase agreements. The denominator in the debt-service calculation comprises tax revenues plus grants from the state budget. 
22. This being said, municipalities and regions are sometimes worryingly resistant to the disclosure of information, particularly deficit and debt figures. Indeed, the Ministry of Finance and other authorities typically avoid independently publishing data on individual regions or municipalities for fear of legal action by the regions and municipalities. In addition, though certain items must now be publicly available on the web it is not all that easy for a non-expert citizen to use this information to make cost comparisons. Only the most recent two years of accounts have to be shown and there are no requirements on presentation. ${ }^{14}$ The defensive attitude of sub-national government on transparency sends bad signals to both the central authorities and the electorate. But, perhaps more importantly, it compromises local democracy by making it difficult for the local press and citizens to have a comprehensive view on the accounts. Various measures could be taken to tackle this issue, in particular:

- Further development of the Ministry of Finance's on-line "ARIS" database of regional and municipal accounts. For instance, the introduction of facilities to make comparisons and nontechnical nomenclature of accounting items readily available would help accessibility. The database could also be used to develop various basic cost indicators that would be of interest to local citizens (e.g. per-capita spending calculations on specific items).

- Widening the legal powers of the Supreme Audit Office to allow full audits of municipalities. This could usefully bolster the surveillance provided by the regular auditing system. At present, the Supreme Audit Office can only investigate financial flows connected with grants and transfers for administrative tasks from central government. ${ }^{15}$

23. The use of private-sector auditing of sub-national government accounts should also be reviewed. Under the auditing rules introduced in 2004, municipalities have the option of paying for a privatecompany to perform their annual audit instead of having the audit carried out free-of-charge by their regional administration. ${ }^{16}$ Some research suggests that the municipalities who choose this option are often in financial difficulty. While this might in part reflect a genuine desire of local officials for expert opinion, it might also reflect a belief among municipalities that private-sector auditors are more likely to use leeway in accounting regulation to present a favourable picture of a municipality's financial position compared with government auditors. A close eye should therefore be kept on the use of private-sector audits by the municipalities and regions.

14. Examination of a small sample of municipal websites by the Secretariat revealed that some municipalities go further than minimum requirements in the level of detail and number of years of accounts. However, none of the websites made assessment of the evolution of spending over time particularly easy. The annual accounts were presented on separate pages and would require spreadsheet skills to cut and paste the accounts into a comparable format. There was also no development of comparisons with costs in other municipalities.

15. The Supreme Audit Office does not have direct powers to initiate legal proceedings based on its reports. However, cabinet regularly discusses the reports and a special committee in the chamber of deputies passes on recommendations to the main budget committee. Publication of the reports also means pressure for reform can come via the media.

16. The auditing system has undergone a number of changes in recent years. Prior to 2003, municipal audits were carried out by the Districts. When the Districts were dissolved in 2002, a temporary system involving widespread private-sector auditing was introduced. However, as part of conditions for EU entry the Czech authorities agreed to introduce a system with stronger state involvement in the auditing process. 


\section{Should the regions and municipalities have more flexibility in financing?}

24. The division between tied and untied revenue is sometimes hotly debated between central and sub-national government in the Czech Republic. For instance there are ongoing debates about grants for teachers' salaries and the corporatisation of regional hospitals. In the case of teachers' salaries, the regions claim that the current system of direct grants for teachers' wages and nationally negotiated wage increases do not give enough flexibility and that non-earmarked funding and regionally-based pay negotiation would be preferable. Those defending the current system argue that there is already sufficient leeway in salaries around $12 \%$ of wages can be allocated at the discretion of school directors - and that there is anyway strong ground-level support for national wage scales. The debate about the corporatisation of hospitals is also partly about wage flexibility (see Box .4). However there are other issues, for instance in theory the corporatised hospitals also have greater freedom in developing fee-paying services. Opponents of corporatisation claim that this will encourage cream skimming and undesirable diversion of attention from core health care services towards fee-based services.

\section{Box 4. Regional financing of hospitals: the debate on corporatisation}

Some regions have converted the hospitals under their jurisdiction from government enterprise (príspĕvková organizace) into standard business enterprises. ${ }^{1}$ One of the main points of contention over this move relates to wage setting. As standard business enterprises, the corporatised hospitals have more freedom in wage setting as there is no obligation to follow the centralised health care wage agreements that normally apply to the sector. This is regarded as a key advantage by the regions but health-worker unions and the current Ministry of Health say it threatens centralised bargaining which they argue already provides sufficient discretion in wage setting. Critics of the move to corporatisation say it threatens universal provision, and that the profit motive will lead to cream skimming and a damaging diversion of managerial focus and resources into fee-based auxiliary services. Parenthetically, in terms of financial oversight there are arguably advantages from corporatisation because it means that the hospitals are subject to standard company accounting rules which provide more transparency compared with those applied to príspěvková organizace.

1. The př́spĕvková organizace is a special form of government enterprise that is part way between a government agency and normal business enterprise. The enterprise is registered as a business and has separate accounts from government. However the accounting rules are not the same as for normal business enterprises and the owners (e.g. municipalities) have special powers in how the enterprise is run. The main activity of the enterprise is typically "nonprofit" but some "for profit" activities are also carried out.

25. Abstracting from the politics of these debates, assessment suggests that although the broad thrust of policy should be towards giving more flexibility in revenue-use to the Czech regions and municipalities, some important caveats apply. Many international experts on sub-national government finance think that, in general, block grants should be used for financing and that there are only certain circumstances where earmarked grants are suitable (see, for example OECD, 2005a). ${ }^{17}$ The chief arguments are that earmarked grants give little incentive for sub-national government to make services efficient and involve considerable administrative burdens compared with non-earmarked grants. The share of sub-national government financing through earmarked grants in the Czech Republic indeed appears to be high in relation to other countries (Figure 5), suggesting that the financing system is out of line with the norm in this respect. However, there are two important reasons for caution in moving towards non-earmarked grants (or similar alternatives such as increased tax allocation):

17. Earmarked grants are recognised as preferable in some specific circumstances, for example when there are positive spill-over effects in services across municipalities. Under block grants, or other untied funding provision is likely to be sub-optimal in this instance. 
- In spending areas where there are significant upcoming challenges and a need for major systemwide reform, removing links between grants and spending is risky because central government may lose too much leverage and reform can be uneven and un-coordinated.

- Granting more flexibility in the use of revenues would place more reliance on local democracy and more reliance on ex post rather than ex ante monitoring of resource allocation by central government. Therefore, it is important that cost and output measurement systems enabling comparison across jurisdictions have reached a satisfactory stage of development. As discussed above, comparisons using regional and municipal accounts are not yet that easy to make. In addition, though benchmarking is underway, none of the initiatives has yet developed into a comprehensive nation-wide system (see discussion below).

Figure 5. Sub-national government revenue from grants and taxes ${ }^{1}$ Per cent of GDP

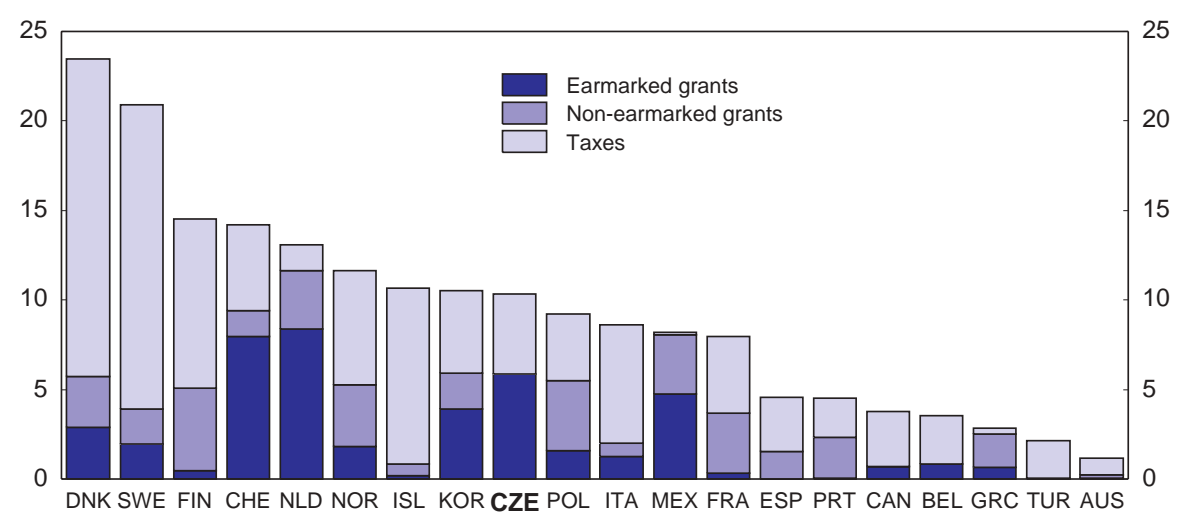

1. The calculations use preliminary 2003 data, except for the Czech Republic which has been updated to 2005. Source: OECD.

26. At the same time, some more room for regions and municipalities in discretionary taxation is warranted. At present only a very small share of municipal revenue is raised by local taxes and fees and regional government has no instruments for local revenue raising. One solution would be to widen the scope using real-estate taxation. Under the current system, municipalities can only alter the rate on some types of building and only within a limited range.

\section{Accountability}

\section{Public procurement: how to clamp down on abuse?}

27. Municipalities and regions tender out about two-thirds of the total value of public procurement contracts in the Czech Republic and therefore having a procurement system that works well at levels of government is important. ${ }^{18}$ Unfortunately, the procurement system has been vulnerable to abuse and much of this at the sub-national government level. For instance, reports by Transparency International paint a dismal picture of widespread collusion between bidders or favouritism in offering tenders (Transparency

18. According to the latest available figures (for 2003), public procurement is equivalent to $18 \%$ of GDP and municipalities and regions are responsible for about two-thirds of this. 
International, 2005a and 2005b). A common strategy is to split contracts so that they fall below the threshold requiring stringent procurement rules (see Box 5 for further examples). ${ }^{19}$

28. Legislative changes made in 2004 and 2006 have aimed to clamp down on abuse and violation of procurement regulation. The 2004 Public Procurement Act introduced new rules regarding contract extensions, tenders involving firms employing disabled people and central records of procurement activity. ${ }^{20}$ It also established a "white list", comprising firms with good track-records in procurement. However, for technical reasons relating to EU entry, the 2004 Act was rushed through parliament and in some respects was not an adequate piece of legislation. A new act has been passed this year that deals with these shortfalls and endeavours to make further improvement to the system. In particular, the 2006 Procurement Act should make procurement easier for small municipalities. Facilities for joint procurement have been introduced. And, the Act allows for a "tender dialogue" in which the tender is initially specified in general terms and the details then fleshed out following exchanges with potential providers. ${ }^{21}$ Though the new Act clearly marks some improvement, further refinement will undoubtedly be needed. For instance, there are concerns that it will not solve problems in the abuse of subjective criteria.

\section{Box 5. Examples of abuses and violations of Czech public procurement rules}

Contract splitting. Segmentation of contracts so that the value of each contract falls below the cut-off point for a strict public tender process.

Abuse of procurement rules for network industries. Municipalities sometimes classify contracts as network services because of lighter procurement rules.

Use of contract extensions to manipulate the system. For instance, there is sometimes collusion between officials and companies in which the firm makes a low (possibly loss-making) bid but, by prior agreement, it is later awarded profitable contract extensions.

Rigging of tender terms of reference and invitations to tender to favour certain bidders, for example through use of subjective criteria in selecting the bidder.

Fixing of the bidding process by firms. For instance, either firms collude (e.g. agreeing to take it in turns to win contracts) or separate bids are made by firms that have strong ownership and management connections.

Abuse of positive discrimination rules. Czech procurement legislation contains provisions allowing contracting authorities to favour bidding firms which employ disabled persons. Reportedly, small firms (with the required criteria) are sometimes used as fronts for getting contracts.

Abuse of complaints procedures. For example failed bidders reportedly threaten to lodge a complaint (which, at the very least postpones the execution of the contract) as a means of putting pressure on the contracting authority to grant other contracts.

Source: Transparency International (2005a).

19. For a general overview of issues public procurement see OECD (2002).

20. The 2004 procurement legislation introduced a rule that to benefit from positive discrimination in the employment of disabled persons, firms must have at least 25 employees (with at least half of them classified as disabled).

21. Other measures in the 2006 procurement act that should help regions and municipalities are provisions allowing common platforms for tenders ("tender frameworks") which should reduce the administration in setting up tenders with similar characteristics. In addition, an electronic auction system has been established and a new system for the procurement of regular supplies (e.g. office supplies) has been set up. 
29. More fundamental structural changes to improve oversight and transparency also need to be considered. Oversight of public procurement is rather limited. Two bodies have legal powers to oversee procurement, the competition authority (the Office for the Protection of Competition) and the Supreme Audit Office. The competition authority can take action if there is transgression of procurement legislation, but this is reportedly often inadequate for catching many forms of abuse. The Supreme Audit Office can undertake more in-depth investigation, but only ex post and it does not have any concrete powers, for instance to enforce a new tendering process (however the influence of its reports via parliament and the media may prompt such action). The Supreme Audit Office is also limited to investigating procurement involving state funds. In addition, transparency of the procurement process is patchy. Parts of the procurement process and related information are subject to specific requirements for public notice (notably the advertising of bids) but some other information is difficult to access. Prague has taken a welcome lead in going beyond legal requirements by publishing details of all its procurement contracts on line, other jurisdictions should be encouraged to follow this example.

\section{Output and cost indicators and benchmarking: only a minority of municipalities are involved}

30. Reasonable progress is being made in developing indicators of municipal activities. Out of the various pilot projects so far set up, the most comprehensive involves the voluntary participation of municipalities of extended scope. ${ }^{22}$ The project began in 2004 and is funded by the participants and a small subsidy from the Ministry of Interior. Initially the project focussed on state-administration (i.e. delegated powers) but it has since been extended to also cover all the key aspects of own responsibilities as well; around 60 specific areas of municipality activity are now covered and there are well over 1000 indicators. The indicators focus on not only public-service providers but also the core administration involved in managing provision. Cost and output in core administration is captured, not only by indicators based on employment and wage costs in municipal offices, but also by data on activities, such as auditing and caseloads. For the public services themselves, the indicators are inevitably more diverse. For instance, the indicators on schooling measure spending per pupil while indicators on road development look at construction and servicing costs per kilometre. So far, the indicator database has not been made public indeed it can only be accessed by participants of the network.

31. Another important benchmarking project was launched last year that aims to develop cost and output indicators in number of key public services as a complement to other benchmarking exercises. At present the project involves service providers in five regions. The Ministry of Interior has so far provided all the funding for the project, though the aim is for regions and municipalities to contribute in the future. The project has to date developed indicators of social services for the elderly (e.g. housing, quality of care, costs and disability levels) but there are plans for it to extend into health care, public transport and cultural activities. $^{23}$

32. However, participation in these benchmarking projects is limited. In the general benchmarking exercise, only about 50 (i.e. about one quarter) of the municipalities of extended scope have so far joined the network. In the project launched more recently, about 85 service providers are participating. Interest in these benchmarking projects is reportedly widening, but not very quickly and additional incentives to encourage participation are needed if these, and other, benchmarking projects are to mature into comprehensive nationwide systems. EU funding opportunities may provide one way of encouraging

22. The project described is one of several benchmarking projects set up over the past few years. For example one began in the early 2000 s looking at measuring cost efficiency in waste treatment. For a general discussion on issues in benchmarking, see OECD, $2005 \mathrm{~b}$.

23. Municipalities play a key role in Czech housing policy as they have wide discretion in responsibility to meet local housing needs. Central financial support comes from the State budget and from the budget of the State Housing Development Fund. Regions only play a minor role in this policy area. 
participation. However, central government should also consider stepping up its support, for instance with subsidies to cover the cost of participation.

\section{E-government: making use of potential}

33. Internet-based information and contact services can improve sub-national government's communication with its electorate and enhance democratic oversight, though of course much depends on the diffusion of Internet access in households and businesses as well as on the availability of the services themselves. ${ }^{24}$ Internet systems can also be used to improve the efficiency of communication between levels of government. Indeed, in the Czech context, the returns to improvements in communication and administrative systems given the very large number of municipalities are potentially large.

34. Reasonable progress is being made on these fronts. Most sub-national governments now have websites and these can be accessed via the central-government portal (www.portal.gov.cz). ${ }^{25}$ Various information databases relevant to municipal and regional government (e.g. land registration) and some disclosure requirements (e.g. on public procurement) have been on line for some time. In addition, legislation introduced this year requires that all mandatory public notices are available on the web and that, whenever feasible, administrative services must be available online. Municipalities were given free electronic signatures on a temporary basis in 2005 in an effort to encourage them to use Internet options in formal communication with other levels of government and citizens.

35. This being said, the Czech government's Economic Growth Strategy (Czech Government, 2005) suggests that the set-up cost for users of electronic signatures needs to be brought down. While the subscription costs for the signatures are not high, there are relatively expensive up-front software costs. Some progress is already being made on this front; the Ministry of Informatics aims to develop alternative software with the intention of providing it free of charge to sub-national governments and households. The Strategy also suggests introducing financial incentives for using government services online. Some caution is needed on this issue as services such as online tax returns can save households time and effort as well as government administration, so adding financial incentives may not be necessary to encourage use. Finally, the Strategy suggests that better co-ordination between some government databases would cut back on red tape, businesses in particular report they often have to submit the same information more than once to the authorities.

\section{Ensuring co-ordinated reform: the case of family policy}

36. The distribution of responsibilities across different layers of government can pose problems for policy co-ordination. Family policy is a case in point. International experience underscores the importance of strong policy co-ordination between the various policies that affect how long, and when, parents take time out of the workforce to care for their children. There is mounting evidence that the costs (in terms of damaged job and career prospects) of taking prolonged breaks from work for childcare are high. Good practice therefore means ensuring contiguous support for working families. For instance, tax-breaks and allowances for children should not be biased in favour of staying at home, child-care facilities need to pick up when statutory parental leave ends and services for older children are needed to make the working day feasible for those with children at primary and secondary school.

24. Recent analysis of implementation issues in e-government can be found in OECD (2005d).

25. The central-government internet portal gives access to all state legislation in its original form and many sites in the portal contain practical advice and application forms for households and businesses. In terms of transaction services, on-line registration of sickness insurance by employers has proved very popular. Several taxes, including income-tax, VAT and excise duty can now be filed on line and some taxes and fees can be paid directly (e.g. the television licence). 
37. In the Czech case, a key challenge is ensuring co-ordination between financial support (tax relief and cash benefits) and childcare services. Family tax relief is centrally administered and the majority of family benefit is state-run (administered by Labour Offices). In contrast, decisions on child-care facilities are essentially in the hands of municipalities, though with some regulation and financial assistance by state government. A strategic document on family policy in 2005 (Ministry of Labour and Social Affairs, 2005) puts forward an ambitious range of reforms including: provisions for spreading parental leave across the first few years of childcare, support of home working and part-time work, and adjustments to kindergarten opening hours. Clearly moving forward on some of these fronts will require considerable co-ordination between central and sub-national government. 
ECO/WKP(2006)27

\section{Bibliography}

Czech Government (2005), Economic Growth Strategy.

Ladner, A. and R. Steiner (2003): Die Schweizer Gemeinden im Wandel: Konvergenz oder Divergenz?, Swiss Political Science Review 9(1), 233-259.

Ministry of Interior (2004), Public Administration in the Czech Republic, Prague.

Ministry of Labour and Social Affairs, National Strategy for Family Policy, Prague.

OECD (2002), Government Procurement: A Synthesis Report, OECD, Paris.

OECD (2003), OECD Territorial Reviews: Moravska Trebova-Jevicko, Czech Republic, OECD, Paris.

OECD (2004), OECD Territorial Reviews: Czech Republic, OECD, Paris.

OECD (2005a), "Intergovernmental Transfers and Decentralised Public Spending", COM/CTPA/ECO/COV(2005)4, September.

OECD (2005b), Modernising Government: the Way Forward, OECD, Paris.

OECD (2005c), OECD Economic Surveys: Czech Republic, OECD, Paris.

OECD (2005d), e-Government for Better Government, OECD, Paris.

Transparency International (2005a), Public Procurement in the Czech Republic: Corruption or Transparency?, Prague.

Transparency International (2005b), "Clientelistic Map” - Monitoring of Construction Public Contracts in Municipalities, Prague.

World Bank (2005), Intergovernmental Fiscal Relations in the New EU Countries, Washington, D.C. 


\section{Annex 1 \\ Incentives for municipalities to merge in the tax-allocation system}

There are incentives for municipalities to merge embedded in the tax-sharing system because the percapita allocation increases with population size. For instance, municipalities with a population of less than 100 get a per-capita allocation based on a coefficient of 0.4213 , while the coefficient for municipalities with populations between 101 and 200 persons is $27 \%$ higher at 0.537 (see table below).

At first glance the lack of response by municipalities to this incentive is perhaps puzzling. For instance, the table below shows an example where a merger could bring a nearly $40 \%$ increase in percapita tax allocation revenue. However, a number of factors have to be considered:

- For small and medium-sized municipalities there are only two points in the schedule where there is a significant increase in the coefficient, at population sizes 100 and 10000 . This consideration, along with geographic factors, limits the possibilities for particularly advantageous mergers among groups of smaller municipalities.

- The tax-share allocation is only about one quarter of total revenue among small municipalities. Therefore, in terms of total revenue the merger incentive is considerably weaker. Indeed, the sums of money involved in mergers would likely be quite small. Based on 2004 accounts, municipalities with population of 70 inhabitants each received about CZK 250000 and municipalities with populations of 140 got CZK 645000 -implying that a merger of two municipalities of 70 would yield only CZK 145000 , less than $€ 5000$.

- There can be a political resistance to merge. The population of a very small municipality may feel they will completely lose collective representation following a merger. 
Table A.1. Merger incentives in the tax-allocation formula Population

\begin{tabular}{|c|c|c|c|c|c|c|c|c|c|}
\hline From & To & Coefficient & $\begin{array}{c}\text { Number of } \\
\text { municipalities } \\
\text { (as of January } \\
\text { 2005) }\end{array}$ & $\begin{array}{c}\text { Total } \\
\text { population }\end{array}$ & $\begin{array}{l}\text { Average } \\
\text { size }\end{array}$ & $\begin{array}{c}\% \\
\text { increase in } \\
\text { coefficient }\end{array}$ & $\begin{array}{l}\text { Population } \\
x \\
\text { coefficient }\end{array}$ & $\begin{array}{l}\text { Share of } \\
\text { tax per } \\
\text { capita (\%) }\end{array}$ & $\begin{array}{l}\text { Share of } \\
\text { tax for } \\
\text { each size } \\
\text { class }\end{array}$ \\
\hline 0 & 100 & 0.4213 & 557 & 39781 & 71 & & 16760 & 0.0000042 & 0.2 \\
\hline 101 & 200 & 0.537 & 1086 & 163101 & 150 & 27 & 87585 & 0.0000053 & 0.9 \\
\hline 201 & 300 & 0.563 & 890 & 219090 & 246 & 5 & 123348 & 0.0000056 & 1.2 \\
\hline 301 & 1500 & 0.5881 & 2850 & 1879116 & 659 & 4 & 1105108 & 0.0000058 & 10.9 \\
\hline 1501 & 5000 & 0.5977 & 592 & 1508730 & 2549 & 2 & 901768 & 0.0000059 & 8.9 \\
\hline 5001 & 10000 & 0.615 & 137 & 932726 & 6808 & 3 & 573626 & 0.0000061 & 5.7 \\
\hline 10001 & 20000 & 0.7016 & 68 & 955227 & 14047 & 14 & 670187 & 0.0000069 & 6.6 \\
\hline 20001 & 30000 & 0.7102 & 28 & 698025 & 24929 & 1 & 495737 & 0.0000070 & 4.9 \\
\hline 30001 & 40000 & 0.7449 & 9 & 320827 & 35647 & 5 & 238984 & 0.0000074 & 2.4 \\
\hline 40001 & 50000 & 0.8142 & 5 & 231511 & 46302 & 9 & 188496 & 0.0000080 & 1.9 \\
\hline 50001 & 100000 & 0.8487 & 16 & 1157242 & 72328 & 4 & 982151 & 0.0000084 & 9.7 \\
\hline 100001 & 150000 & 1.0393 & 1 & 100752 & 100752 & 22 & 104712 & 0.0000103 & 1.0 \\
\hline & $150000+$ & 1.6715 & 3 & 841758 & 280586 & 61 & 1406998 & 0.0000165 & 13.9 \\
\hline & Prague & 2.7611 & 1 & 1170571 & 1170571 & 65 & 3232064 & 0.0000273 & 31.9 \\
\hline Total & & & 6243 & 10218457 & & & 10127525 & & 100 \\
\hline
\end{tabular}

Two hypothetical examples of mergers:

1) Merger of five municipalities each with a population of 70

$\begin{array}{ll}\text { Co-efficients before the merger } & 0.4213 \\ \text { Co-efficient after the merger } & 0.5881 \\ \text { Increase per-capita tax allocation (\%) } & 39.6 \\ \text { Implied increase in revenue (assuming taxes roughly } 1 / 4 \text { of revenue) (\%) } & 9.9\end{array}$

2) A municipality with a population of 9700 merges with five municipalities each having a population of 70
Average coefficient before the merger:
0.6083
Co-efficient after the merger
0.7016

Increase \%

Implied increase in revenue (assuming taxes roughly $1 / 4$ of revenue) (\%) 3.8

Source: Ministry of Finance; OECD calculations. 


\section{Annex 2}

\section{The structure of municipalities' delegated powers}

The majority of delegated powers are designated to the 205 "municipalities of extended scope" (or municipalities of the "third type") and the subsidiary layer of 388 of municipalities of the "second type" (see main text). Together these two types of municipalities have responsibilities in the following broad areas of state administration: population registration and identity cards, management of school budgets, building regulation and land planning, roads, vehicle registration and traffic offences, state social welfare and environmental issues.

The system works as follows. Territorially, a particular group of municipalities is divided up under, say, one municipality of extended scope and several municipalities of the second type.

- Within the group of municipalities, some responsibilities are assigned only to the relevant municipality of extended scope. Examples of these are administration relating to school budgets, identity cards, trade licensing offices, vehicle registration and traffic violations.

- Other responsibilities are divided between the municipalities of extended scope and municipalities of the second type. The most notable of these is administration of social welfare. For instance, within the particular group of municipalities some have their welfare offices run by a municipality of extended scope, while others are be run by municipalities of the second type.

- In a number of activities assignment is split between the municipality of extended scope and the municipalities of second type, depending on the specific service. For instance, municipalities of the second type are responsible for administration relating to local roads only while the municipalities of extended scope are also responsible for administration relating to second and third-level roads. 


\section{WORKING PAPERS}

The full series of Economics Department Working Papers can be consulted at www.oecd.org/eco/Working_Papers/

498. Policies to Promote Innovation in the Czech Republic (July 2006) Alessandro Goglio

497. Getting Education Right for Long-Term Growth in the Czech Republic (July 2006) Alessandro Goglio

496. Assessing the 2005 Czech Proposals for Pension Reform (July 2006) Philip Hemmings and Edward Whitehouse

495. Poland's Education and Training: Boosting and Adapting Human Capital (July 2006) Paul O’Brien and Wojciech Paczynski

494. The Rates and Revenue of Bank Transaction Taxes (July 2006) Jorge Baca-Campodónico, Luiz de Mello and Andrei Kirilenko

493. Nothing Ventured, Nothing Gained: The Long-Run Fiscal Reward of Structural Reforms (July 2006 Peter Hoeller and Claude Giorno

492. Ireland's Housing Boom: What has Driven It and Have Prices Overshot? (June 2006) Dave Rae and Paul van den Noord

491. Boosting Competition in Ireland (June 2006) Dave Rae, Line Vogt and Michael Wise

490. Factors Behind Low Long-Term Interest Rates (June 2006) Rudiger Ahrend, Pietro Catte and Robert Price

489. The Fiscal Challenge in Portugal (June 2006) Stéphanie Guichard and Willi Leibfritz

488. Are House Prices Nearing a Peak? A Probit Analysis for 17 OECD Countries (June 2006) Paul van den Noord

487. Maintaining Switzerland's Top Innovation Capacity (June 2006) Florence Jaumotte

486. Employment Patterns in OECD Countries: Reassessing the Role of Policies and Institutions (June 2006) Andrea Bassanini and Romain Duval

485. Brazil's Fiscal Stance During 1995-2005: The Effect of Indebtedness on Fiscal Policy Over the Business Cycle (May 2006) Luiz de Mello and Diego Moccero

484. Realising the Oil Supply Potential of the CIS: The Impact of Institutions and Policies (May 2006) Rudiger Ahrend and William Tompson

483. Summary of a workshop on global convergence scenarios: structural and policy issues (May 2006) Nick Vanston 


\section{ECO/WKP(2006)27}

482. Revised OECD methods for supply-side and medium-term assessment: a capital services approach (July 2006) Pierre-Olivier Beffy, Patrice Ollivaud, Pete Richardson and Frank Sédillot

481. Balancing health care quality and cost containment: the case of Norway (February 2006) Alexandra Bibbee and Flavio Padrini

480. The ageing challenge in Norway: ensuring a sustainable pension and welfare system (February 2006) Benoît Bellone and Alexandra Bibbee

479. Strengthening innovation in the Netherlands: Making better use of knowledge creation in innovation activities (February 2006) David Carey, Ekkehard Ernst, Rebecca Oyomopito and Jelte Theisens

478. How to sustain growth in a resource based economy? The main concepts and their application to the Russian case

(February 2006) Rudiger Ahrend

477. Projecting $O E C D$ health and long-term care expenditures: What are the main drivers? (February 2006)

476. Alternative measures of well-being (January 2006) Romina Boarini, Åsa Johansson and Marco Mira D'Ercole

475. Recent house price developments: the role of fundamentals (January 2006) Nathalie Girouard, Mike Kennedy, Paul van den Noord and Christophe André

474. Reforming federal fiscal relations in Austria (January 2006) Andrès Fuentes, Eckhard Wurzel and Andreas Wörgötter

473. Product market competition and economic performance in France Concurrence sur les marchés de produits et performance économique en France (January 2006) Jens Høj and Michael Wise

472. Product market reforms and employment in OECD countries (December 2005) Giuseppe Nicoletti and Stefano Scarpetta

471. Fast-falling barriers and growing concentration: the emergence of a private economy in China (December 2005) Sean Dougherty and Richard Herd

470. Sustaining high growth through innovation: reforming the $R \& D$ and education systems in Korea (December 2005) Yongchun Baek and Randall Jones

469. The labour market in Korea: enhancing flexibility and raising participation (December 2005) Randall Jones

468. Getting the most out of public-sector decentralization in Korea (December 2005) Randall Jones and Tadashi Yokoyama

467. Coping with the inevitable adjustment in the US current account (December 2005) Peter Jarrett

466. Is there a case for sophisticated balanced-budget rules? (December 2005) Antonio Fatás

465. Fiscal rules for sub-central governments design and impact (December 2005) Douglas Sutherland, Robert Price and Isabelle Joumard 